\title{
PEMANFAATAN OLI BEKAS SEBAGAI BAHAN BAKAR ALTERNATIF KOMPOR YANG RAMAH LINGKUNGAN
}

\author{
Andi Kusnadi), Romi Djafar ${ }^{2)}$, Mustofa ${ }^{3)}$ \\ ${ }^{1}$ Mahasiswa Program Studi Mesin dan Peralatan Pertanian, Politeknik Gorontalo \\ ${ }^{2,3}$ Dosen Program Studi Mesin dan Peralatan Pertanian, Politeknik Gorontalo \\ e-mail: romidjafar@poligon.ac.id
}

\begin{abstract}
ABSTRAK
Saat ini telah ada beberapa orang atau kelompok masyarakat yang telah memanfaatkan oli bekas sebagai bahan bakar. Namun pemanfaatan ini hanya untuk penggunaan pengerjaan tertentu bukan untuk kalangan umum, seperti untuk bahan bakar pembakaran Batu Gamping, dan Peleburan Aluminium. Minimnya pemanfaatan ini akan mengakibatkan jumlah oli bekas akan terus bertambah dan membuat oli bekas ini menjadi bahan yang rawan untuk mencemari lingkungan.Berdasarkan latar belakang diatas maka penulis akan melakukan penelitian dengan metode studi pustaka, dengan judul "Pemanfaatan Limbah Oli sebagai Bahan Bakar Kompor Alternatif Ramah Lingkungan". Karakteristik limbah oli yang paling bagus untuk dijadikan bahan bakar kompor alternatif adalah yang memiliki viskositas terendah $(10,58 \mathrm{cts})$ sebagai hasil pemanasan hingga suhu $100^{\circ} \mathrm{C}$ dimana oli bekas relatif telah berubah menjadi agak cair sehingga nantinya oli bekas tersebut mudah untuk didorong menuju ke mulut bakar kompor alternatif menggunakan tekanan udara. Tinggi lidah api yang dihasilkan pada pembakaran oli bekas $>25 \mathrm{~cm}$ dengan suhu $>222,2^{\circ} \mathrm{C}$ dengan nilai energi kalor terbesar $3,735 \mathrm{kal} /$ detiknya. Nilai efisiensi oli bekas tertinggi yang tercapai adalah sebesar 4,94\%, yang apabila dibandingkan dengan efisiensi minyak tanah memang lebih kecil, namun apabila memasukkan variable keterdapatan oli bekas yang lebih melimpah dibandingkan dengan keterdapatan minyak tanah di masyarakat, penggunaan oli bekas menjadi sebuah bahan bakar kompor alternatif akan tetap lebih hemat biaya daripada menggunakan minyak tanah sebagai bahan bakarnya.
\end{abstract}

Kata Kunci: Limbah, Oli bekas, Kompor, Bahan bakar, Efisiensi.

\section{ABSTRACT}

There are some people or community groups who have used used oil as fuel. However, this utilization is only for the use of certain works not for the general public, such as fuel for burning limestone, and aluminum smelting. The lack of utilization will result in the amount of used oil will continue to grow and make this used oil a material that is prone to pollute the environment. Based on the background above, the author will conduct research with literature study methods, with the title "Utilization of Oil Waste as a Friendly Alternative Stove Fuel Environment". The characteristics of the best oil waste to be used as alternative stove fuel is the one that has the lowest viscosity (10.58 cts) as a result of heating to a temperature of $1000 \mathrm{C}$ where the used oil has relatively turned into a bit liquid so that later used oil is easy to be pushed into the mouth of the burn alternative stoves use air pressure. The height of the flame produced on the combustion of used oil $>25 \mathrm{~cm}$ with a temperature $>222.20 \mathrm{C}$ with the largest heating energy value of $3.735 \mathrm{cal} / \mathrm{sec}$. The highest value of used oil efficiency achieved is $4.94 \%$, which when compared to the efficiency of kerosene is indeed smaller. However, when entering the variable used oil density which is more abundant compared to the kerosene density in the community, the use of used oil becomes a fuel alternative stoves will still be more cost effective than using kerosene as fuel.

Keywords: Waste, used oil, stove, fuel, efficiency. 


\section{PENDAHULUAN}

\section{Latar Belakang}

Energi merupakan hal yang sangat penting dalam kehidupan manusia untuk berbagai kebutuhan. Energi pada umumnya digunakan untuk berbagai keperluan seperti memasak, bahan bakar kendaraan, industri dan lain sebagainya. Saat ini energi yang digunakan mayoritas bersumber dari minyak bumi yang didapat dari hasil tambang. Akibat penggunaanya dilakukan terus - menerus, kini ketersediaanya semakin lama semakin berkurang, maka tersedianya bahan bakar alternatif sangatlah diperlukan untuk mengurangi pengunanaan Gas Elpiji.

Saat ini telah ada beberapa orang atau kelompok masyarakat yang telah memanfaatkan oli bekas sebagai bahan bakar. Namun pemanfaatan ini hanya untuk penggunaan pengerjaan tertentu bukan untuk kalangan umum, seperti untuk bahan bakar pembakaran Batu Gamping, dan Peleburan Aluminium..

Pemanfaatan secara terbatas ini apabila diperbandingkan dengan ketersediaan ataupun dengan kecepatan pertambahan oli bekas di kalangan masyarakat umum, maka akan tergolong sangatlah minim. Minimnya pemanfaatan ini akan mengakibatkan jumlah oli bekas akan terus bertambah dan membuat oli bekas ini menjadi bahan yang rawan untuk mencemari lingkungan.

Berdasarkan hal diatas maka penulis akan melakukan penelitian dengan metode studi pustaka, dengan judul "Pemanfaatan Limbah Oli sebagai Bahan Bakar Kompor Alternatif Ramah Lingkungan".

\section{Rumusan Masalah}

- Bagaimana limbah oli bekas dapat dijadikan bahan bakar kompor alternatif?

- Bagaimana karakteristik nyala api kompor alternatif berbahan bakar oli bekas

- Bagaimana efisiensi Kompor Alternative Berbahan Bakar Oli Bekas Dibandingkan Bahan Bakar Minyak Tanah?

\section{Tujuan}

- Mengindentifikasi karakteristik berbagai limbah oli bekas bahan bakar kompor alternatif

- Menentukan nilai energi kalor kompor alternatif berbahan limbah oli bekas

- Menentukan nilai efesiensi kompor alternatif berbahan bakar limbah oli bekas

\section{Manfaat}

Beberapa manfaat yang diperoleh dari hasil penetian adalah:

- Mengetahui nilai-nilai/parameter pengujian bahan bakar pada limbah oli kendaraan.

- Mengetahui kontribusi penggunaan limbah oli bekas sebagai bahan bakar kompor alternatif menghasilkan efisiensi biaya dan efisiensi kecepatan waktu memasak.

- Menambah referensi bagi mahasiswa lain pada khususnya dan bagi masyarakat pada umumnya untuk menggunakan limbah oli kendaraan sebagai bahan bakar kompor alternatif yang memberikan keuntungan biaya dan waktu yang cukup signifikan.

\section{METODE PENELITIAN}

\section{Jenis dan Pendekatan Penelitian}

Jenis dan pendekatan penelitian pada tugas akhir ini menggunakan metode penelitian kajian kepustakaan. Yang dimaksud penelitiankepustakaan adalah penelitian yang dilakukan hanya berdasarkan atas karya tertulis, termasuk hasil penelitian baik yang telah maupun yang belum dipublikasikan (Embun, 2012).

Penelitian dengan studi literatur tidak harus turun kelapangan dan bertemu dengan responden. Data-data yang dibutuhkan dalam penelitian dapat diperoleh dari sumber pustaka atau dokumen. Menurut (Zed, 2014), pada riset pustaka (library research), penelusuran pustaka tidak hanya untuk langkah awal menyiapkan kerangka penelitian (research design) akan tetapi sekaligus memanfaatkan sumber - sumber perpustakaan untuk memperoleh data penelitian.

Selain data, beberapa hal yang harus ada dalam sebuah penelitian supaya dapat dikatakan ilmiah, juga memerlukan hal lain seperti rumusan masalah, landasan teori, analisis data, dan pengambilan kesimpulan. Penelitian dengan studi literatur adalah penelitian yang persiapannya sama dengan penelitian lainnya akan tetapi sumber dan metode pengumpulan data dengan mengambil data di pustaka, membaca, mencatat, dan mengolah bahan penelitian.

\section{Sumber Data}

Sumber data penelitian tugas akhir ini diperoleh dari karya ilmiah berupa jurnal-jurnal elektronik (e- 
jurnal) atau dokumen-dokumen atau karya ilmiah berupa tulisan tugas akhir terdahulu yang banyak ditemukan di internet.

\section{Pengumpulan Data}

Untuk memperoleh data yang diinginkan, terlebih dahulu dilakukan pengumpulan / inventarisasi kata kunci / keyword yang berkaitan dengan jenis bahan bakar alternatif, serta kriteria - kriteria pengujian suatu jenis bahan bakar untuk kemudian dimasukkan ke dalam kolom dari salah satu mesin pencarian di media internet, dalam hal ini google search engine(mesin pencari google) di situs www.google.com.

\section{Analisis Data}

Data-data yang diperoleh dari jurnal - jurnal elektronik, selanjutnya diolah. Pengolahan data bertujuan untuk mempermudah dalam melakukan analisis data. Teknik analisa data yang digunakan ada 2 macam, yaitu analisa deskriptif dan analisa inferensial. Analisa Deskriptif adalah analisa yang berhubungan dengan metode pengelompokan dan peringkasan data sehingga penyajian data akan lebih informatif. Analisa inferensial dilakukan untuk mencari hubungan antara variable satu dengan yang lain kemudian menentukan sebuah kesimpulanterhadap variabel tersebut. Kedua metode analisis ini tersaji dalam tabel-tabel pada bab pembahasan.

\section{HASIL DAN PEMBAHASAN}

\section{Energi}

Besaran energi dari oli bekas tercermin dari nilai kalor yang dihasilkan oli bekas itu sendiri seperti yang digambarkan dalam bab sebelumnya..

Berdasarkan data yang diambil hasil dari penelitian olehAhmad Hamri, dkk (2016) bahwa nilai kalor oli bekas adalah sebesar 10.684,912 Kcal/kg.

Dalam penelitian oleh Ahmad Amri (2019) ini, tangki bahan bakar yang digunakan dapat menampung oli bekas sebanyak $100 \mathrm{cc}$, dimana untuk oli bekas sebanyak $100 \mathrm{cc}$ tersebut habis terpakai dalam waktu 4,00 menit (Ahmad Amri, 2019, hal. 6). Dasar perhitungan nilai energi kalor yang dihasilkan oli bekas pada setiap penambahan tekanan diambil dari langkah - langkah perhitungan energi kalor yang dihasikan oli bekas pada penambahan tekanan sebesar 2,5 bar, yang tercantum dalam penelitian Ahmad Amri (2019) halaman 6. Berikut ini perincian perhitungan energi yang dihasilkan oleh oli bekas dalam proses water boiling test sejumlah massa air. Perhitungan energi kalor yang dihasilkan pada
penambahan tekanan sebesar 0,5 bar

- Perhitungan penggunaan oli bekas per detiknya untuk pemanasan 1 liter air

a. Pada percobaan yang dilakukan, oli bekas dengan volume sebesar $100 \mathrm{cc}$ habis terpakai dalam waktu 4,00 menit. Hal ini berarti bahwa dalam tiap detiknya, bahan bakar oli bekas yang terpakai sebanyak $100 \mathrm{cc} / 4,0$ menit atau sebesar 0,417 cc/detik.

b. Dari percobaan diketahui juga bahwa waktu keseluruhan yang diperlukan oli bekas untuk memanaskan air sebanyak 1 liter adalah 10,0 menit.

c. Jumlah oli bekas yang digunakan untuk memanaskan air, berdasarkan hasil perkalian silang $\frac{100 \text { cc Bahan bakar }}{4,0 \text { menit }} \times \frac{10 \text { menit }}{1 \text { liter air }}$ yaitu 1000 cc bahan bakar per 10 menit. Hal ini berarti total volume oli bekas yang terpakai sebanyak $250 \mathrm{cc}$.

d. Massa dari oli bekas yang digunakan, diperoleh dari hasil perkalian massa jenis oli bekas dengan volume, dimana 1 liter $=1000 \mathrm{cc}$. Sehingga massa oli bekas yang digunakan sebesar $=250,0 \mathrm{cc} \times 0,839 \mathrm{gr} / \mathrm{cm}^{3}=209,75 \mathrm{gr}$ atau sebesar $0,209 \mathrm{~kg}$.

- Perhitungan laju konsumsi bahan bakar oli bekas untuk pemanasan 1 liter air diperoleh dari pembagian massa oli bekas yang digunakan dengan total waktu yang diperlukan $=\frac{0,209 \mathrm{~kg}}{10 \times 60 \text { detik }}=$ $0,000348 \mathrm{~kg} /$ detik.

- Perhitungan kebutuhan energi untuk memanaskan air 1 liter dengan tekanan 0,5 bar. Perhitungan ini akan menggunakan rumus:

$$
\begin{aligned}
Q=\frac{\mathrm{mxc \times} \Delta \mathrm{T}}{t}= & \frac{1 \mathrm{~kg} \text { air } \times 1 \frac{\mathrm{Kcal}}{\mathrm{kg}^{0} \mathrm{C}} \times(99,8-27)^{0} \mathrm{C}}{600 \text { detik }} \\
& =0,121 \frac{\mathrm{Kcal}}{\text { detik }}
\end{aligned}
$$

- Nilai energi kalor yang dihasilkan dengan penambahan tekanan 0,5 bar

Energi kalor yang dihasilkan $=$ nilai kalor $\mathrm{x}$ laju konsumsi bahan bakar

$=10.684,92 \times 0,000348$

$=3,722 \mathrm{kal} / \mathrm{detik}$

Perhitungan energi kalor yang dihasilkan pada penambahan tekanan sebesar 1,0 bar

- Perhitungan penggunaan oli bekas per detiknya untuk pemanasan 1 liter air

a. Pada percobaan yang dilakukan, oli bekas dengan volume sebesar $100 \mathrm{cc}$ habis terpakai dalam waktu 4,00 menit. Hal ini berarti bahwa dalam tiap detiknya, bahan bakar oli bekas 
yang terpakai sebanyak $100 \mathrm{cc} / 4,0$ menit atau sebesar 0,417 cc/detik.

b. Dari percobaan diketahui juga bahwa waktu keseluruhan yang diperlukan oli bekas untuk memanaskan air sebanyak 1 liter adalah 9,76 menit.

c. Jumlah oli bekas yang digunakan untuk memanaskan air, berdasarkan hasil perkalian silang $\frac{100 c c \text { Bahan bakar }}{4,0 \text { menit }} \times \frac{9,76 \text { menit }}{1 \text { liter air }}$ yaitu 976 cc bahan bakar per 4 menit. Hal ini berarti total volume oli bekas yang terpakai sebanyak 244 , cc.

d. Massa dari oli bekas yang digunakan, diperoleh dari hasil perkalian massa jenis oli bekas dengan volume, dimana 1 liter $=1000$ cc. Sehingga massa oli bekas yang digunakan sebesar $=244 \mathrm{cc} \times 0,839 \mathrm{gr} / \mathrm{cm}^{3}=204,716 \mathrm{gr}$ atau sebesar $0,204 \mathrm{~kg}$.

- Perhitungan laju konsumsi bahan bakar oli bekas untuk pemanasan 1 liter air diperoleh dari pembagian massa oli bekas yang digunakan dengan total waktu yang diperlukan = $\frac{0,204 \mathrm{~kg}}{9,76 \times 60 \text { detik }}=0,00035 \mathrm{~kg} /$ detik.

- Perhitungan kebutuhan energi untuk memanaskan air 1 liter dengan tekanan 1,0 bar. Perhitungan ini akan menggunakan rumus:

$$
\begin{aligned}
Q=\frac{\operatorname{mxc} \times \Delta \mathrm{T}}{t}= & \frac{1 \mathrm{~kg}_{\text {air }} \times 1 \frac{\mathrm{Kcal}}{\mathrm{kg}^{0} \mathrm{C}} \times(99,8-27)^{0} \mathrm{C}}{9,76 \times 60 \mathrm{detik}} \\
& =0,124 \frac{\mathrm{Kcal}}{\text { detik }}
\end{aligned}
$$

- Nilai energi kalor yang dihasilkan dengan penambahan tekanan 1,0 bar

Energi kalor yang dihasilkan $=$ nilai kalor $\mathrm{x}$ laju konsumsi bahan bakar

$=10.684,92 \times 0,000348$

$=3,7352 \mathrm{kal} / \mathrm{detik}$

1. Perhitungan energi kalor yang dihasilkan pada penambahan tekanan sebesar 1,5 bar

- Perhitungan penggunaan oli bekas per detiknya untuk pemanasan 1 liter air

a. Pada percobaan yang dilakukan, oli bekas dengan volume sebesar $100 \mathrm{cc}$ habis terpakai dalam waktu 4,00 menit. Hal ini berarti bahwa dalam tiap detiknya, bahan bakar oli bekas yang terpakai sebanyak $100 \mathrm{cc} / 4,0$ menit atau sebesar $0,417 \mathrm{cc} /$ detik.

b. Dari percobaan diketahui juga bahwa waktu keseluruhan yang diperlukan oli bekas untuk memanaskan air sebanyak 1 liter adalah 8,56 menit. c. Jumlah oli bekas yang digunakan untuk memanaskan air, berdasarkan hasil perkalian silang $\frac{100 c c \text { Bahan bakar }}{4,0 \text { menit }} \times \frac{8,56 \text { menit }}{1 \text { liter air }}$ yaitu 856 cc bahan bakar per 4 menit. Hal ini berarti total volume oli bekas yang terpakai sebanyak 214 , cc.

d. Massa dari oli bekas yang digunakan, diperoleh dari hasil perkalian massa jenis oli bekas dengan volume, dimana 1 liter $=1000 \mathrm{cc}$. Sehingga massa oli bekas yang digunakan sebesar $=214 \mathrm{cc} \mathrm{x} 0,839 \mathrm{gr} / \mathrm{cm}^{3}=179,546 \mathrm{gr}$ atau sebesar $0,179 \mathrm{~kg}$.

- Perhitungan laju konsumsi bahan bakar oli bekas untuk pemanasan 1 liter air diperoleh dari pembagian massa oli bekas yang digunakan dengan total waktu yang diperlukan $=\frac{0,179 \mathrm{~kg}}{8,56 \times 60 \text { detik }}=$ $0,00035 \mathrm{~kg} /$ detik.

- Perhitungan kebutuhan energi untuk memanaskan air 1 liter dengan tekanan 1,50 bar. Perhitungan ini akan menggunakan rumus:

$$
\begin{aligned}
Q=\frac{\mathrm{mxcx} \Delta \mathrm{T}}{t}= & \frac{1 \mathrm{~kg}_{\text {air }} \times 1 \frac{\mathrm{Kcal}}{\mathrm{kg}^{\circ} \mathrm{C}} \times(99,8-27)^{\circ} \mathrm{C}}{8,56 \times 60 \text { detik }} \\
& =0,142 \frac{\text { Kcal }}{\text { detik }}
\end{aligned}
$$

- Nilai energi kalor yang dihasilkan dengan penambahan tekanan 1,50 bar

Energi kalor yang dihasilkan $=$ nilai kalor $\mathrm{x}$ laju konsumsi bahan bakar

$=10.684,92 \times 0,00035$

$=3,7352 \mathrm{kal} / \mathrm{detik}$

\section{Perhitungan energi kalor yang dihasilkan pada} penambahan tekanan sebesar 2,0 bar

- Perhitungan penggunaan oli bekas per detiknya untuk pemanasan 1 liter air

a. Pada percobaan yang dilakukan, oli bekas dengan volume sebesar $100 \mathrm{cc}$ habis terpakai dalam waktu 4,00 menit. Hal ini berarti bahwa dalam tiap detiknya, bahan bakar oli bekas yang terpakai sebanyak $100 \mathrm{cc} / 4,0$ menit atau sebesar $0,417 \mathrm{cc} /$ detik.

b. Dari percobaan diketahui juga bahwa waktu keseluruhan yang diperlukan oli bekas untuk memanaskan air sebanyak 1 liter adalah 7,36 menit.

c. Jumlah oli bekas yang digunakan untuk memanaskan air, berdasarkan hasil perkalian silang $\frac{100 c c \text { Bahan bakar }}{4,0 \text { menit }} \times \frac{7,36 \text { menit }}{1 \text { liter air }}$ yaitu 736 cc bahan bakar per 4 menit. Hal ini berarti total volume oli bekas yang terpakai sebanyak 184 , cc. 
d. Massa dari oli bekas yang digunakan, diperoleh dari hasil perkalian massa jenis oli bekas dengan volume, dimana 1 liter $=1000$ cc. Sehingga massa oli bekas yang digunakan sebesar $=184 \mathrm{cc} \times 0,839 \mathrm{gr} / \mathrm{cm}^{3}=154,376 \mathrm{gr}$ atau sebesar $0,154 \mathrm{~kg}$.

- Perhitungan laju konsumsi bahan bakar oli bekas untuk pemanasan 1 liter air diperoleh dari pembagian massa oli bekas yang digunakan dengan total waktu yang diperlukan = $\frac{0,154 \mathrm{~kg}}{7,36 \times 60 \text { detik }}=0,00035 \mathrm{~kg} /$ detik.

- Perhitungan kebutuhan energi untuk memanaskan air 1 liter dengan tekanan 2,0 bar. Perhitungan ini akan menggunakan rumus:

$$
\begin{aligned}
Q=\frac{\mathrm{mxcx} \Delta \mathrm{T}}{t}= & \frac{1 \mathrm{~kg} \text { air } \times 1 \frac{\mathrm{Kcal}}{\mathrm{kg}^{0} \mathrm{C}} \times(99,8-27)^{0} \mathrm{C}}{7,36 \times 60 \text { detik }} \\
& =0,165 \frac{\mathrm{Kcal}}{\text { detik }}
\end{aligned}
$$

- Nilai energi kalor yang dihasilkan dengan penambahan tekanan 1,0 bar

Energi kalor yang dihasilkan $=$ nilai kalor $\mathrm{x}$ laju konsumsi bahan bakar

$=10.684,92 \times 0,00035$

$=3,7352 \mathrm{kal} / \mathrm{detik}$

3. Perhitungan energi kalor yang dihasilkan pada penambahan tekanan sebesar 2,5 bar

- Perhitungan penggunaan oli bekas per detiknya untuk pemanasan 1 liter air

a. Pada percobaan yang dilakukan, oli bekas dengan volume sebesar $100 \mathrm{cc}$ habis terpakai dalam waktu 4,00 menit. Hal ini berarti bahwa dalam tiap detiknya, bahan bakar oli bekas yang terpakai sebanyak $100 \mathrm{cc} / 4,0$ menit atau sebesar $0,417 \mathrm{cc} /$ detik.

b. Dari percobaan diketahui juga bahwa waktu keseluruhan yang diperlukan oli bekas untuk memanaskan air sebanyak 1 liter adalah 6,57 menit.

c. Jumlah oli bekas yang digunakan untuk memanaskan air, berdasarkan hasil perkalian silang $\frac{100 c c \text { Bahan bakar }}{4,0 \text { menit }} \times \frac{6,57 \text { menit }}{1 \text { liter air }}$ yaitu 657 cc bahan bakar per 4 menit. Hal ini berarti total volume oli bekas yang terpakai sebanyak 164,25 , cc.

d. Massa dari oli bekas yang digunakan, diperoleh dari hasil perkalian massa jenis oli bekas dengan volume, dimana 1 liter $=1000 \mathrm{cc}$. Sehingga massa oli bekas yang digunakan sebesar $=164,25 \mathrm{cc} \times 0,839 \mathrm{gr} / \mathrm{cm}^{3}=137,80 \mathrm{gr}$ atau sebesar $0,137 \mathrm{~kg}$.
- Perhitungan laju konsumsi bahan bakar oli bekas untuk pemanasan 1 liter air diperoleh dari pembagian massa oli bekas yang digunakan dengan total waktu yang diperlukan = $\frac{0,137 \mathrm{~kg}}{6,57 \times 60 \text { detik }}=0,00035 \mathrm{~kg} /$ detik.

- Perhitungan kebutuhan energi untuk memanaskan air 1 liter dengan tekanan 2,50 bar. Perhitungan ini akan menggunakan rumus:

$$
\begin{aligned}
Q=\frac{\mathrm{mxc \times \Delta T}}{t}= & \frac{1 \mathrm{~kg}_{\text {air }} \times 1 \frac{\mathrm{Kcal}}{\mathrm{kg}^{0} \mathrm{C}} \times(99,8-27)^{\circ} \mathrm{C}}{6,57 \times 60 \mathrm{detik}} \\
& =0,165 \frac{\mathrm{Kcal}}{\text { detik }}
\end{aligned}
$$

- Nilai energi kalor yang dihasilkan dengan penambahan tekanan 1,0 bar

Energi kalor yang dihasilkan $=$ nilai kalor $\mathrm{x}$ laju konsumsi bahan bakar

$=10.684,92 \times 0,00035$

$=3,7352 \mathrm{kal} / \mathrm{detik}$

Berdasarkan data tersebut, dapat dibuat tabel perbandingan antara penambahan tekanan pada oli bekas dan besaran energi kalor yang dihasilkan pada setiap penambahan tekanan tersebut.

\begin{tabular}{|c|c|c|c|c|}
\hline No & Referensi & $\begin{array}{l}\text { Nilai kalor } \\
\text { (Kcal/kg) }\end{array}$ & $\begin{array}{l}\text { Tekanan } \\
\text { (P) } \\
\text { (Bar) }\end{array}$ & $\begin{array}{l}\text { Energi } \\
\text { Kalor yang } \\
\text { dihasilkan } \\
\text { (kal/detik) }\end{array}$ \\
\hline 1 & $\begin{array}{l}\text { Ahmad } \\
\text { Amri } \\
\text { (2019) }\end{array}$ & $10.684,92$ & $\begin{array}{l}0,5 \\
1,0 \\
1,5 \\
2,0 \\
2,5\end{array}$ & $\begin{array}{l}3,722 \\
3,735 \\
3,735 \\
3,735 \\
3,735\end{array}$ \\
\hline
\end{tabular}

Tabel 1. Perbandingan penambahan tekanan pada oli bekas dan besaran energi kalor yang dihasilkan oleh oli bekas pada setiap penambahan tekanan.

Dari hasil perhitungan energi kalor yang dihasilkan di atas, didapatkan grafik hubungan penambahan tekanan terhadap energi kalor yang dihasilkan, seperti yang tersaji dalam gambar 1 .

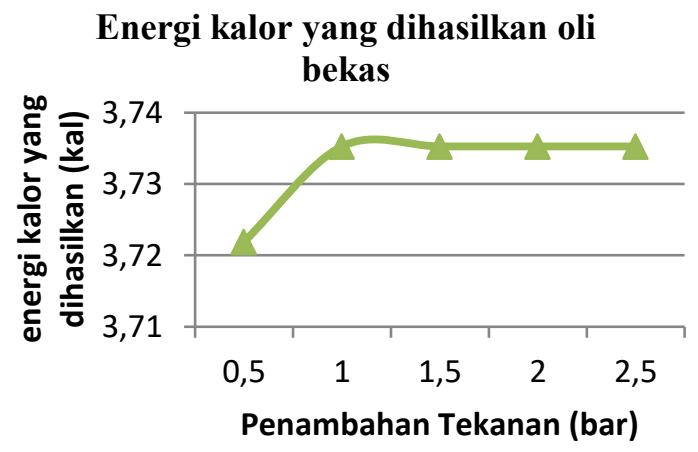

Gambar 1. Grafik hubungan penambahan tekanan terhadap energi kalor yang dihasilkan 
Dengan melihat grafik di atas, dapat ditarik kesimpulan bahwa pada percobaan tersebut, energi kalor tertinggi yang dihasilkan oli bekas mencapai nilai 3,735 kal/detik. Kesimpulan lain yang bisa diambil yaitu bahwa penambahan tekanan hingga batas 1 bar akan menambah pula energi kalor yang dihasilkan, namun pada penambahan tekanan setiap 0,5 bar selanjutnya, tidak ada lagi penambahan energi kalor. Hal ini dikarenakan penambahan tekanan yang diterapkan pada konsentrasi oli bekas akan membuat konsumsi bahan bakar oli bekas akan bertambah pula. Hal ini berarti tetap saja bahwa setiap partikel oli bekas yang terbakar menghasilkan energi panas yang tetap, tidak meningkat, atau stagnan.

\section{Efesiensi}

Efisiensi penggunaan oli bekas menjadi sebuah bahan bakar alternatif diperoleh dari hasil pembagian besaran energi yang dibutuhkan per detik dari oli bekas dalam memanaskan air sebanyak 1 liter dengan laju konsumsi bahan bakar dan nilai kalor dari oli bekas itu sendiri (Ahmad Amri, 2019, hal. 6).

Berikut ini perhitungan efisiensi oli bekas pada setiap penambahan tekanan yang dilakukan.

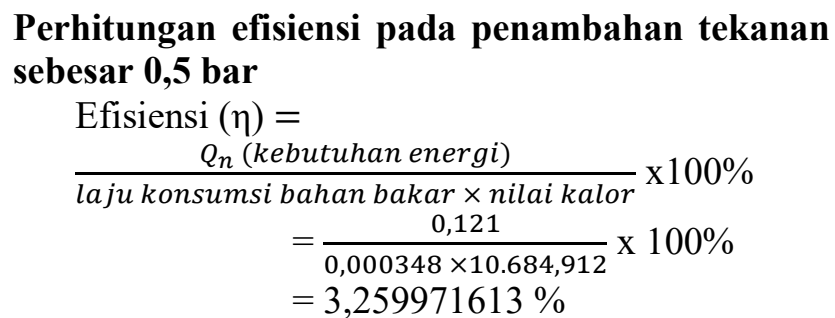

Perhitungan efisiensi pada penambahan tekanan sebesar 1,0 bar

Efisiensi $(\eta)=$

$\frac{Q_{n}(\text { kebutuhan energi })}{\text { laju konsumsi bahan bakar } \times \text { nilai kalor }} \times 100 \%$

$=\frac{0,124}{0,000349 \times 10.684,912} \times 100 \%$

$=3,328191578 \%$

Perhitungan efisiensi pada penambahan tekanan sebesar 1,5 bar

Efisiensi $(\eta)=$

$\frac{Q_{n}(\text { kebutuhan energi })}{\text { laju konsumsi bahan bakar } \times \text { nilai kalor }} \times 100 \%$

$=\frac{0,142}{0,000349 \times 10.684,912} \times 100 \%$

$=3,794760491 \%$

Perhitungan efisiensi pada penambahan tekanan sebesar 2,0 bar

Efisiensi $(\eta)=$

$\frac{Q_{n}(\text { kebutuhan energi })}{\text { laju konsumsi bahan bakar } \times \text { nilai kalor }} \times 100 \%$

$=\frac{0,164}{0,000349 \times 10.684,912} \times 100 \%$

$=4,41347144 \%$
Perhitungan efisiensi pada penambahan tekanan sebesar 2,5 bar

Efisiensi $(\eta)=$

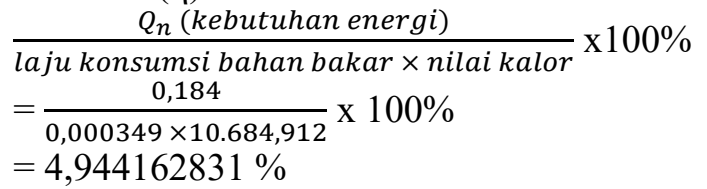

Berdasarkan perhitungan di atas, dapat dibuat tabel efisiensi pada setiap penambahan tekanan, sebagai berikut :

Tabel 2. Nilai efisiensi oli bekas terhadap tekanan

\begin{tabular}{cccc}
\hline No & Referensi & $\begin{array}{c}\text { Penambahan } \\
\text { Tekanan (P)(bar) }\end{array}$ & $\begin{array}{c}\text { Efisiensi } \\
(\boldsymbol{\eta})(\mathbf{\%})\end{array}$ \\
\hline $\mathbf{1}$ & Ahmad & 0,5 & 3,259 \\
& Amri & 1,0 & 3,328 \\
& $(2019)$ & 1,5 & 3,794 \\
& & 2,0 & 4,413 \\
& & 2,5 & 4,944 \\
\hline
\end{tabular}

Berdasarkan tabel di atas, maka nilai efisiensi oli bekas yang dihasilkan pada percobaan Ahmad Amri dkk (2019) berada dalam rentang 3,26 - 4,94 \%, dimana nilai efisiensi terbesar $(4,94 \%)$ tercapai pada penambahan tekanan sebesar 2,5 bar.

Secara rinci, efisiensi yang dihasilkan oleh oli bekas mengalami peningkatan ketika ditambahkan tekanan. Hal ini terjadi karena ketika ditambahkan tekanan pada oli bekas tersebut, kebutuhan energi dalam proses pendidihan air perdetiknya semakin besar. Peningkatan kebutuhan energi yang harus dikeluarkan perdetik tercermin pada penurunan waktu dalam proses pendidihan air akibat penambahan tekanan itu sendiri. Sementara itu, laju konsumsi bahan bakar pada oli bekas yang telah ditambahkan tekanan tidak lagi mengalami peningkatan.

Laju konsumsi bahan bakar pada oli bekas mengalami peningkatan hanya ketika oli bekas ditambahkan tekanan pada batas 1,0 bar. Dengan ditambahkan tekanan pada oli bekas, membuat kebutuhan energi dalam proses pendidihan mengalami peningkatan namun tidak membuat laju konsumsi bahan bakar meningkat pula. Dengan meningkatnya kebutuhan energi dalam proses pendidihan air untuk setiap penambahan tekanan yang tidak dibarengi dengan peningkatan laju konsumsi bahan bakar inilah yang menyebabkan nilai efisiensi dari oli bekas bisa terus mengalami peningkatan mengingat bahwa efisiensi merupakan hasil pembagian besaran energi yang dibutuhkan per detik dari oli bekas dalam memanaskan air sebanyak 1 liter dengan laju konsumsi bahan bakar dan nilai kalor dari oli bekas itu sendiri. 


\section{Kesimpulan}

Dari hasil kajian pustaka yang dilakukan, dapat diambil beberapa kesimpulan, yaitu :

- Karakteristik limbah oli yang paling bagus untuk dijadikan bahan bakar kompor alternatif adalah yang memiliki viskositas terendah $(10,58 \mathrm{cts})$ sebagai hasil pemanasan hingga suhu $100^{\circ} \mathrm{C}$ dimana oli bekas relatif telah berubah menjadi agak cair sehingga nantinya oli bekas tersebut mudah untuk didorong menuju ke mulut bakar kompor alternatif menggunakan tekanan udara.

- Nyala api yang dihasilkan kompor alternatif berbahan bakar oli bekas mempunyai panjang lidah api $>25 \mathrm{~cm}$ dengan suhu $>222,2^{\circ} \mathrm{C}$ yang menghasilkan nilai energi kalor terbesar 3,735 kal/detiknya.

- Nilai efisiensi oli bekas tertinggi yang tercapai adalah sebesar 4,94\%, yang apabila dibandingkan dengan efisiensi minyak tanah memang lebih kecil. Namun apabila memasukkan variable keterdapatan oli bekas yang lebih melimpah dibandingkan dengan keterdapatan minyak tanah di masyarakat, penggunaan oli bekas menjadi sebuah bahan bakar kompor alternatif akan tetap lebih hemat biaya daripada menggunakan minyak tanah sebagai bahan bakarnya.

\section{REFERENSI}

Amri Ahmad, Hamri, Fikar Adriansyah Sofyan. 2016.Analisis Nilai Ekonomis Oli Bekas Pada Kompor Bertekanan Berpemanas Awal.Universitas Muslim Indonesia.

Antony Agus.2014. Rancang Bangun Dan Uji Performa Alat Burner Babingtong Dengan Menggunakan Bahan Bakar Oli Bekas Dan Minyak Jelantah.Skripsi. Fakultas Teknik Universitas Iba, Palembang.

Asidu, La Ode Asman Darsono, Hasbi Muhammad, Aksar Prinob. 2017. Pemanfaatan Minyak Oli Bekas Sebagai Bahan Bakar Alternatif Dengan Pencampuran Minyak Pirolisis. Jurnal Mahasiswa Teknik Mesin - Universitas Halu Oleo,vol. 2 no 2 Juni 2017.

Hudoyo, Roy. dkk. 2013. Pengujian Pengaruh Penambahan Material Pengotor Oli Bekas Jenuh Sebagai Identifikasi Kandungan Energ Pada Oli Murni. Prosiding Seminar Nasional Sains dan Pendidikan Sains VIII, Fakultas Sains dan Matematika Universitas Kristen Satya Wacana, Salatiga, 15 Juni 2013, Vol 4, No 1, ISSN : 2087-0922
Muh.Hasbi., Lilis Laome, Prinob Aksar, Ld. Asman Darsono. 2019. Pemanfaatan Minyak Oli Bekas Sebagai Bahan Bakar Alternatif. Seminar Nasional Teknologi Terapan Inovasi Dan Rekayasa (Snt2ir) 2019 Program Pendidikan Vokasi Universitas Halu Oleo.

Raharjo W.P, 2007. Pemanfaatan TEA (three ethyl amin) dalam proses penjernihan oli bekas sebagai bahan bakar pada peleburan aluminium. Jurnal Penelitian sains \& Teknologi, 8 (2) : 166-184.

Suparta, I Nyoman, dkk.2015. Daur Ulang Oli Bekas Menjadi Bahan Bakar Diesel dengan Proses Pemurnian Menggunakan Media Asam Sulfat dan Natrium Hidroksida. Jurnal METTEK Volume 1 No 2 (2015) pp 9 - 19. Universitas Udayan 